DOI:10.14258/tpai(2021)33(3).-08

УДК 903.4(51)

\title{
NIZHNYAYA SOORU SETTLEMENT IN CENTRAL ALTAI: SOME OUTCOMES OF THE STUDY AND PROSPECTS FOR FURTHER RESEARCH
}

\author{
Alexey A. Tishkin', Taylor Hermes', Sergei P. Grushin' \\ 'Altai State University, Barnaul, Russian Federation; \\ IInstitut for the Study of Human History of the Max Planck Society for Scientific Research, \\ Leipzig, Germany \\ ORCID: https://orcid.org/0000-0002-7769-136X; e-mail: tishkin210@mail.ru \\ ORCID: https://orcid.org/0000-0002-8377-468X; e-mail: taylor_hermes@eva.mpg.de \\ ORCID: https://orcid.org/0000-0002-5404-6632; e-mail: gspl42@mail.ru
}

\begin{abstract}
More than 150 years have passed since V.V Radlov began the first excavations to study the Afanasievo culture in the Altai. To date, mortuary complexes have provided the majority of cultural and biological material for the Afanasievo culture and have served as the basis for robust analyses and interpretations, even though their potential has not been fully exhausted. Critically, Afanasievo settlements have been very poorly studied. One of the most important reasons for this gap in our knowledge is the lack of surveys for occupational sites of communities in the Altai dating to the end of the $4^{\text {th }}$ to the beginning of the $3^{\text {rd }}$ millennium BCE. The available information on the Afanasievo culture gives hope that this research agenda will be eventually implemented. At the same time, it is important to bring existing results into the scientific literature and analyze available materials with modern methods. This article provides information about the Afanasievo settlement Nizhnyaya Sooru, which was discovered in the Karakol River Valley of the central Altai. In spite of the small scale of previous excavations, the findings attracted archaeological attention and have been described in several publications. Inspection of this settlement in 2019 and 2020 revealed that the cultural deposits were actively being destroyed by erosion. Here, we present our observations, photographs, and a topographic plan of the site, while outlining the prospects of future research at Nizhnyaya Sooru.

Keywords: Altai, Afanasievo culture, Nizhnyaya Sooru, settlement, animal bones, ceramics, stone tools, radiocarbon dating, topographic plan

Acknowledgments: The work was carried out with support from the National Geographic Society, № NGS-67706R-20.

For citation: Tishkin A. A., Hermes T., Grushin S. P. Nizhnyaya Sooru Settlement in Central Altai: Some Outcomes of the Study and Prospects for Further Research. Theory and Practice of Archaeological Research. 2021;33(3): 125-141. (In English) DOI: 10.14258/tpai(2021)33(3).-08
\end{abstract}

\section{ПОСЕАЕНИЕ НИЖНЯЯ СООРУ В ЦЕНТРААЬНОМ АЛТАЕ: НЕКОТОРЫЕ ИТОГИ ИЗУЧЕНИЯ И ПЕРСПЕКТИВЫ АААЬНЕЙШИХ ИССАЕАОВАНИЙ А. А. Тишкин', Т. Гермес², С. П. Грушин' \\ 'А^тайский государственный университет, г. Барнаул, Российская Федерация; ${ }^{2}$ Институт эволюционной антропологии Макса Планка, г. Аейпциг, Германия ORCID: https://orcid.org/0000-0002-7769-136X; e-mail: tishkin210@mail.ru ORCID: https://orcid.org/0000-0002-8377-468X; e-mail: taylor_hermes@eva.mpg.de ORCID: https://orcid.org/0000-0002-5404-6632; e-mail: gsp142@mail.ru}


Резюме: Изучение археологических памятников на Алтае, относимых к афанасьевской культуре, насчитывает более 150 лет. Начало этого процесса было заложено раскопками под руководством В.В. Радлова. К настоящему времени при исследовании погребальных комплексов получены существенные по объему научные материалы, которые уже стали предметами всесторонних анализов и интерпретаций, хотя их потенциал до конца не исчерпан. Совсем слабо изученными оказались поселения. Это связано с несколькими факторами, среди которых главный неосуществленные обследования для специальной фиксации мест проживания населения Алтая в конце IV - начале III тыс. до н.э. Имеющиеся сведения позволяют надеяться на перспективность такого направления работ. При этом важно ввести в научный оборот ранее полученные результаты и на современном уровне проанализировать имеющиеся материалы. В данной статье представлена информация о поселении Нижняя Соору, которое было обнаружено в одной из горных долин Центрального Алтая. Несмотря на незначительные по объему раскопки, были получены находки, которые привлекли внимание исследователей, что нашло отражение в нескольких публикациях. Осмотр указанного поселения в 2019 и 2020 гг. обозначил проблему дальнейшего разрушения культурного слоя. Зафиксированные наблюдения, полученные фотоснимки и тахеометрический план памятника представлены в данной статье. Обозначены перспективы дальнейших исследований.

Ключевые слова: Алтай, афанасьевская культура, Нижняя Соору, поселение, кости животных, керамика, каменные орудия, радиоуглеродное датирование, тахеометрический план

Благодарности: Работа выполнена при поддержке Национального географического общества (National Geographic Society), проект №NGS-67706R-20.

Для цитирования: Тишкин А. А., Гермес Т., Грушин С. П. Поселение Нижняя Соору в Центральном Алтае: некоторые итоги изучения и перспективы дальнейших исследований // Теория и практика археологических исследований. 2021. Т. 33, №3. С. 125-141. DOI: 10.14258/ tpai(2021)33(3).-08

\section{$\mathrm{I}$}

\section{ntroduction}

For several decades in Eurasian archaeology much attention has been paid to the so-called Afanasievo culture, the sites of which have been studied over a large region not only in Russia (Altai, Khakasia, Tuva), but also in Eastern Kazakhstan, China (Xinjiang) and Mongolia [Tsyb, 1984; Pogozheva et al., 2006; Burial and settlement complexes..., 2006; Afanasiev Collection, 2010; Afanasiev Collection 2, 2012; Vadetskaya, Polyakov, Stepanova, 2014; Kovalev, 2019; Merz, 2021; Honeychurch et al., 2021; et al.]. Of course, expansion and refinement of the delineated range of the Afanasievo culture is not excluded. In this situation, there is a need to align the accumulated information with the concepts that characterize the archaeological materials at various taxonomic levels. It is absolutely clear, that the available volume of data raises the question on designation of a cultural-historical community, for which there may be sense in abandoning the name "Afanasievo". Regional manifestations of this phenomenon should be considered as separate archaeological cultures, not excluding the identification of local variants [Masson, 1976, fig. 1] and consideration should be made to special types of sites. Therefore, one of us has already expressed the idea of designating the Saldyar culture of the Afanasievo period in the Altai [Surazakov and Tishkin, 2007, p. 86; Tishkin and Seregin, 2012, p. 202; Tishkin, 2018, p. 30], based on the materials of Saldyar-I monument, published as a monograph [Larin, 2005]. 
The possibility of revised designations for the Afanasievo culture requires additional discussions, although the cultural specificity of the studied sites is clearly observed in the known cultural areas, among which the Altai Mountains are paramount. The peculiarities of the Afanasievo culture are mainly based on the results of research on human burials. Such excavations in 1865 were carried out by V. V. Radlov [Kiryushin, 1985], and later under the leadership of S. I. Rudenko in 1924, 1925 and 1929 [Rudenko, 1926; Vadetskaya, Polyakov, and Stepanova, 2014, pp. 34-35; Konstantinov et al., 2018, p. 19]. In the 1930s, they were continued by G. P. Sergeev, G. P. Sosnovsky, and S. V. Kiselev [Sosnovsky, 1941; Kiselev, 1951, pp. 55-59; Vadetskaya, Polyakov, Stepanova, 2014, p. 3; et al.]. The results of this work and later studies were reflected in two dissertations [Tsyb, 1984; Fribus, 1998]. A brief history of the study of the Afanasievo culture of the Altai was published by O. V. Larin [1988]. By the present time there has been published a summary of the sites of the Altai Afanasievo culture [Vadetskaya, Polyakov and Stepanova, 2014, pp. 5-120]. Most of the materials from the mortuary complexes have been analyzed in different aspects [Ancient cultures..., 1994; Larin, 2005; Pogozheva et al., 2006; Grushin et al., 2006; Stepanova, 2019; etc.]. Unfortunately, targeted excavations of settlements were seldom carried out. The obtained materials were put into scientific circulation [Abdulganeev, Kiryushin, and Kadikov, 1982; Pogozheva et al., 2006, pp. 18-26; Mamadakov and Stepanova, 1998; Shulga, 2012; Vadetskaya, Polyakov and Stepanova, 2014, pp. 6-7, 9, 15-16, 23-24, 26-31, 33-34, 36-37, 40-41], but their impact was small. It is the study of the settlements that is worth paying close attention to at present. Such monuments are important for gaining a complete picture when reconstructing the subsistence of the Altai population at the end of the $4^{\text {th }}$ and beginning of the $3^{\text {rd }}$ millennium BCE. Therefore, the purpose of this article is to present small but important results of the study of the Nizhnyaya Sooru settlement located in the Central Altai (Fig. 1.-1). On this basis, it is worth considering the prospects of its excavation.

The Nizhnyaya Sooru settlement is situated about $2 \mathrm{~km}$ south-eastward from Kulada village in the Ongudai region of the Altai Republic (Russia) on the first terrace of the Karakol river near to the modern cattle farms (Fig. 1.-2). The geographic coordinates of its location, fixed by GPS-receiver (WGS-84), are as follows: $\mathrm{N}-50^{\circ} 40.069^{\prime}, \mathrm{E}-085^{\circ} 48.483^{\prime}( \pm 4 \mathrm{~m})$. The altitude above sea level, demonstrated by the same instrument, was about $1110 \mathrm{~m}$, indicating a midmountain zone, which covers the largest area of the Central Altai and has its own geographical features [Kiryushin and Tishkin, 1997, p. 94-97]. The characteristic intermountain valley in the Nizhnyaya Sooru valley, gradually descends and widens closer to the flood plain. According to the local residents of the valley, this lower section is not covered by snowpack in winter because the winds prevent snow accumulation. This circumstance allows cattle to feed on the remaining dry grass in winter, in addition to the use of cultivated fodder. Most likely, the setting of the local valley was an important factor in selecting the area for ancient and modern cattle husbandry.

\section{History of the study of the settlement and the recovered materials}

In the Nizhnyaya Sooru valley, many mortuary and memorial sites have been recorded, which belong to the Afanasievo period, Pazyryk culture, Turkic communities, and modern times. Early Turkic fences were partially investigated by A.S. Vasyutin [Seregin, Vasyutin, 2021]. The results of the excavations of sites attributed to the Eneolithic [Seregin, Vasyutin, 2020], which can be correlated with the Nizhnyaya Sooru settlement, should be mentioned. 
Ancient and modern cult places [Ilyushin, 2011], as well as the results of pictorial activity [Mukhareva, Miklashevich and Seregin, 2021], were identified.

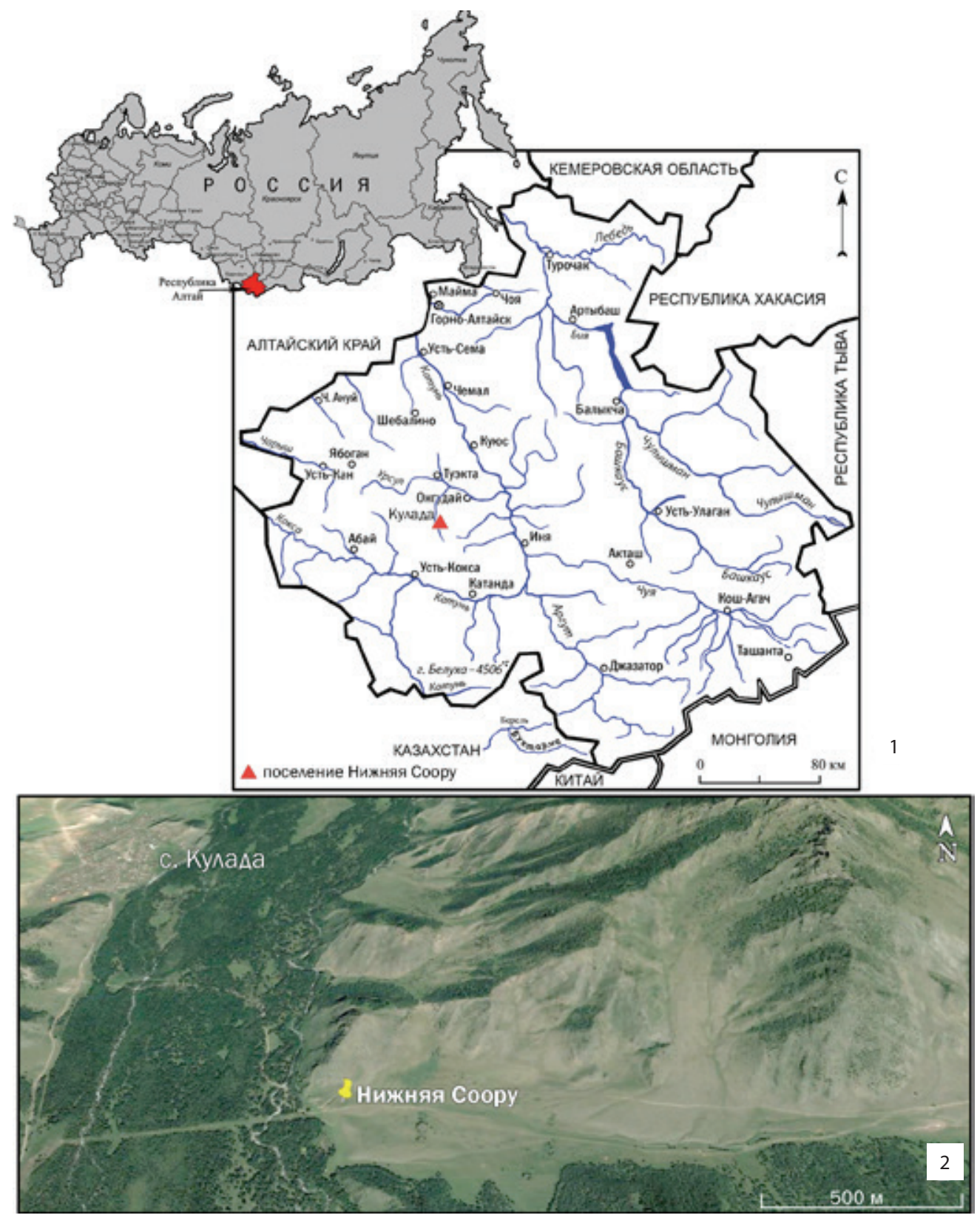

Fig. 1. The location of the settlement of Nizhnyaya Sooru:

1 - on the schematic map; 2 - on a picture from space

Рис. 1. Место расположения поселения Нижняя Соору:

$$
1 \text { - на карте-схеме; } 2 \text { - на снимке из космоса }
$$


The Nizhnyaya Sooru settlement was revealed in 1994 by the Altai archaeologist O. V. Larin, while inspecting the growth of an erosional ravine into the site's boundary. In prevent destruction of the cultural layer, an excavation with an area of only 2.4 square meters was made at the same time [Yelin and Larin, 1998, pp. 66-67]. Information about the findings has been published in detail [Larin, Kungurova and Stepanova, 1998; Kosintsev, 2005]. In 1997 another researcher from Gorno-Altaisk V.A. Kocheev again examined the site and collected surface material [Larin, Kungurova, Stepanova, 1998, p. 67], which is probably stored in the A. V. Anokhin National Museum of the Altai Republic (Gorno-Altaysk). In autumn 1998, the cultural layer of the settlement was examined by Yu.T. Mamadakov and A.A. Tishkin during the Altai excursion with their German colleagues from Dresden (Germany). Very small collections of pottery and bone fragments were obtained, and stone products from the Middle Paleolithic site of the Mousterian industry were found at a nearby quarry [Kungurov and Tishkin, 2000]. At the end of July 2019 (during a planned expedition to Mongolia) further erosion of the settlement was noted and geographical coordinates were recorded by an archaeological detachment of Altai State University led by A. A. Tishkin.

Small excavations at the Nizhnyaya Sooru settlement were planned in 2020. However, due to the pandemic, the expedition did not take place, although S. P. Grushin received an excavation permit. When visiting the monument, it was possible to photograph the extent of the archaeological site and the nature of its erosion (Fig. 2.-1). In particular, it was observed that the cultural deposits were overlaid by a dense layer of coarse gravel, as well as subsequent alluvial deposits, which over time had formed a layer about $0.6 \mathrm{~m}$ thick and was already well sodded (Fig. 2.-2, 3). In some places, a carbonaceous layer was observed (Fig. 2.-4), as well as in the precipice of the ravine there was a visible firepit (Fig. 2.-2).

The thickness of the cultural layer of the Nizhnyaya Soru settlement excavated in 1994 was about $0.16 \mathrm{~m}$. Cultural material (pottery, stone items, animal bones) was rather densely accumulated. The excavation exposed a rectangular feature, embedded in the $\mathrm{C}$ horizon (materik) and consisted of four stone slabs $(32 \times 25 \times 3-4 \mathrm{~cm}$ in size). The bottom of the feature also appeared to be lined with slabs. Soot on the inner walls of the feature suggested it was a hearth. The excavation yielded 33 lithic artifacts, which were analyzed in detail and wear-trace determinations were made [Larin, Kungurova, Stepanova, 1998]. The main lithic finds were chips and splinters. Three blades of irregular outlines were found, which were made with a rather simple technique of cleavage. During the use wear analysis, $\mathrm{N}$. Yu. Kungurova identified three splinted pieces, saws, and burins, indicating that they were used in the manufacture of wooden products. Three grinding tools, which could be used for processing metal objects and a so-called "iron" for smoothing seams on leather items were also found. Two fragments of clay spindle whirls were found. One of them was made from a fragment of a vessel. The recovered ceramic assemblage represents about 25 vessels, including a censer. It was not possible to restore the vessels completely. It was noted that some fragments stylistically differ from the typical Afanasievo pottery [Larin, Kungurova and Stepanova, 1998, p. 72]. 

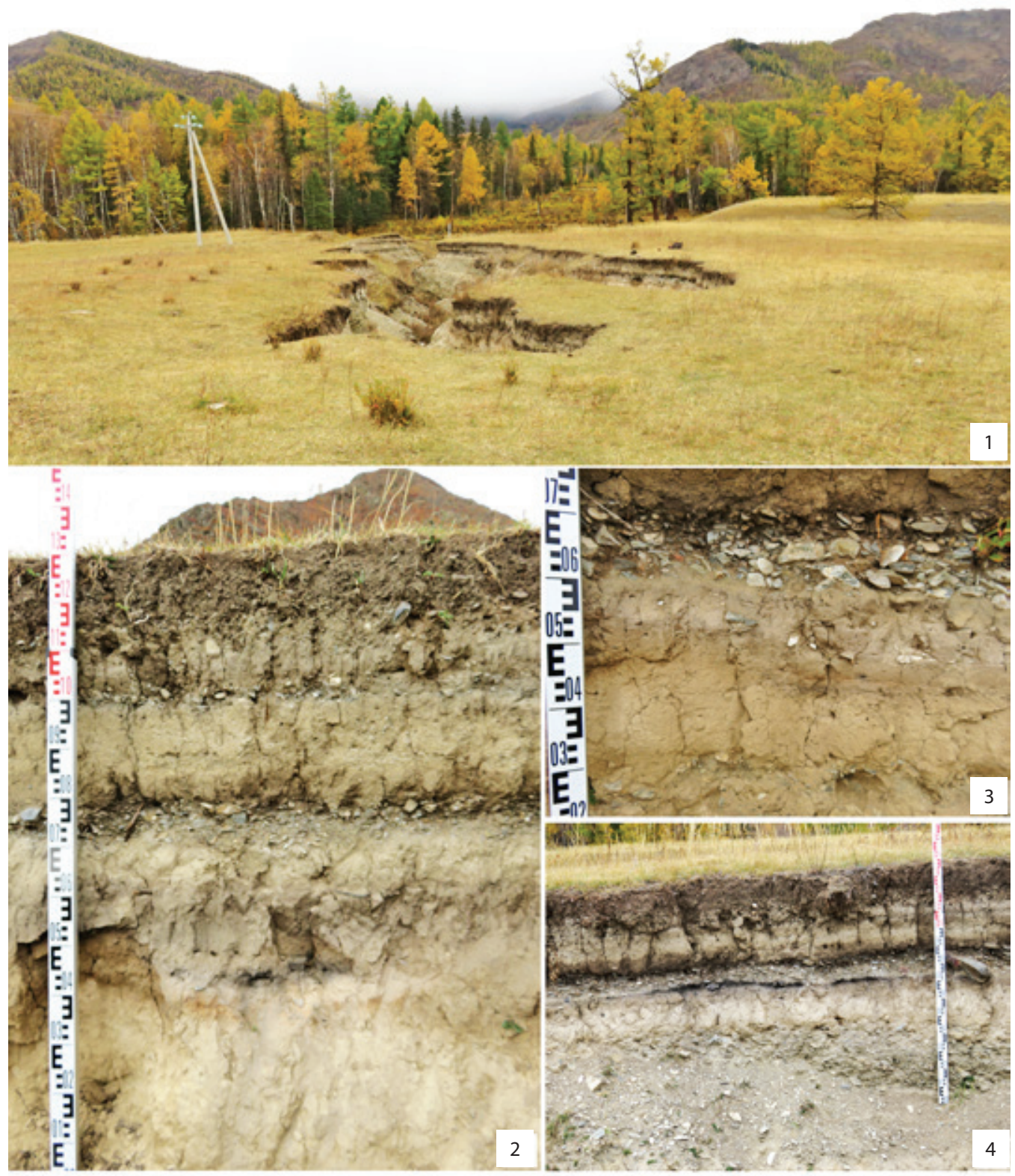

Fig. 2. Nizhnyaya Sooru: 1 - the modern type of destruction; 2 - the wall of the broken ground; 3 - the cultural layer; 4 - the carbonaceous layer

Рис. 2. Нижняя Соору: 1 - современный вид разрушений; 2 - стенка оврага; 3 - культурный слой; 4 - углистая прослойка 
The excavation recovered bones of cattle (41 specimens), caprines (229 specimens), horse (4 specimens), wild animals (separate specimens from deer, fox, badger) and indeterminate remains, of which 198 specimens are closer to mammals. All skeletal elements attributed to caprine belonged to sheep (probably from 19 individuals). According to the wear stages of faunal teeth, P. A. Kosintsev distinguished the following age groups: 6-12 months, seven individuals; $12-24$ months, five individuals; over 24 months, seven individuals. This age composition allowed him to point to the meat productive strategy of sheep husbandry. It was also noted that the sheep of the Afanasievo culture were smaller than the sheep of the Early Bronze Age in southwestern Siberia and Northern Kazakhstan, as well as the Sintashta community [Kosintsev, 2005].

On the basis of the analyzed materials the Nizhnyaya Sooru settlement was attributed to the Afanasievo culture, but absolute dating was not performed. The importance of studying the site as one of the most "pure" of the Afanasievo culture was noted [Larin, Kungurov and Stepanova, 1998, p. 72].

\section{Problems and their discussion}

Selected sheep teeth from the excavations of the Nizhnyaya settlement became the basis for paleogenetic analysis and AMS dating [Hermes et al., 2020]. But before proceeding to a brief overview of these results, it is worth paying attention to some relevant points related to the origin of the Afanasievo culture, the interest in which is recently "heated" by paleogenomic research, during which close genetic affinity between individuals of the Yamnaya cultural community and individuals of the Afanasievo culture (community) was established. On this basis, an unambiguous conclusion is made about the migration of the eastern "Yamnaya" to the region of South Siberia and a corresponding arrow is prominently drawn on the map of the Eurasian steppes representing the early Bronze Age [Allentoft et al., 2015, p. 169, fig. 1]. It makes sense to discuss this situation, as the fact of the alleged mass migration is not so obvious archaeologically and is very problematic. More probable, in our opinion, should be considered the migration of closely related ("pre-Yamnaya") people from one center but in different directions to the Volga and farther east, but not through Northern Kazakhstan, where a completely different (Botai) community prevailed, but possibly through the region of present-day central Kazakhstan. This hypothesis requires testing. However, at the present stage such a point of view does not contradict the available archaeological materials and has already been expressed in a relatively similar form [Fribus, 2006]. The migrants who arrived in Altai, within a narrow time window and nearly across the whole region, found the mountain-valleys suitable for pastoralist herding. In this way, they reconfigured their subsistence strategies that differed sharply from local strategies, which were based on Neolithic foraging and hunting. It is possible that earlier Afanasievo people (before the Altai was reached) lived in similar montane ecosystems. Otherwise they may have stopped in the resource-rich Ob-Irtysh interfluve, as the bearers of the Elunino culture did at the end of the $3^{\text {rd }}$ millennium BCE [Kiryushin, 2002, p. 82-91]. But, it seems, a choice was made in favor of familiar mountain landscapes for pastoralist production. Here, it is worth mentioning that the population of the Andronovo culture did not occupy the Altai Mountains but instead they densely occupied the surrounding foothills in the middle of the $2^{\text {nd }}$ millennium BCE. This pattern is well evidenced by the results of archaeological research. The famous Russian archaeologist M. P. Gryaznov [1955, 1957] 
directly connected the cause of the absence of Bronze Age sites in the Altai Mountains with the economic system of the Andronovo culture (community) being better suited to the lower plains.

The chronological designation the Afanasievo community in the Altai requires clarification. In some publications it is indicated as Eneolithic [for example: Seregin, Vasyutin, 2020], in others as Early Bronze Age [for example: Dashkovsky, Stepanova, 2018], as well as the Bronze Age [for example: Burial and settlement complexes..., 2006] or the Paleometallic era [for example: Dashkovsky, 2019]. The chronological framework of the sites of Afanasievo cultural community studied using radiocarbon dating is defined in a broad chronological framework: from the $2^{\text {nd }}$ half of 4 th to the $1^{\text {st }}$ half of $3^{\text {rd }}$ millennium BCE [Poliakov and Svyatko, 2009, pp. 25-27, fig. 3; Kiryushin et al., 2010, p. 61], which nicely corresponds to the Eneolithic period. This conclusion is also supported by the fact that no bronze artifacts were found in any of the Altai sites of that time. It is clear that Afanasievo metallurgy was limited to copper working [Grushin et al., 2009, pp. 7-23].

The AMS dating of sheep teeth from the Nizhnyaya Sooru settlement and materials from other sites in the Altai (Maly Dugan, Pervy Mezhelik-I) not only marked a chronological interval of 3300-2900 BCE [Hermes et al., 2020], but also pointed to the need for further work on this topic. These dates partially confirmed the previously obtained radiocarbon determinations for the Afanasievo culture. However, the solution of the chronological issues for the sites of the Altai Eneolithic period is still far from reach. No less important were the results of the initial stage of the paleogenetic study of domestic sheep [Hermes et al., 2020]. In our opinion, studies of the osteological materials of these animals together with other data will allow for the determination of the origins of the Afanasievo phenomenon, while also isolating the waves of community movements to the region.

\section{Conclusion}

There is significant prospect for further research at the Nizhnyaya Sooru settlement. By the present time a topographic plan (Fig. 3) has been obtained, which reflects the erosional situation with the site and highlights the Importance of excavations. In addition, geophysical surveys of one of the sites have been conducted. The results of electrotomography are still in progress. The surveys indicate the spread of the cultural layer to the north of the ravine. It is not fixed in the southern wall.

The Nizhnyaya Sooru settlement is a rescue site, which raises the urgency of thorough archeological excavation. The experience of previous works allows us to count on obtaining large amounts faunal skeletal remains for traditional zooarchaeological analysis, proteomics (Zooarchaeology by Mass Spectrometry - ZooMS), paleogenomics, and AMS dating. A separate problem is the determination of the importance of domesticated horses in Afanasievo subsistence. For this, the available finds are still scarce. A separate project remains to be done to further study pottery and stone artifacts, as well as to establish their geographic sources. It makes sense to carry out palynological and phytolithic analyses for environmental reconstructions. Observations of the geomorphological plan are important to understand the processes that took place before and after the formation of the cultural layer. It is crucial to understand the cause of formation of the massive gravel layer, which overlapped and partially disturbed the cultural layer. Thus, future excavations will significantly complement 
and implement the modern program of multidisciplinary research, which will provide critical new information about the still poorly understood Afanasievo culture.

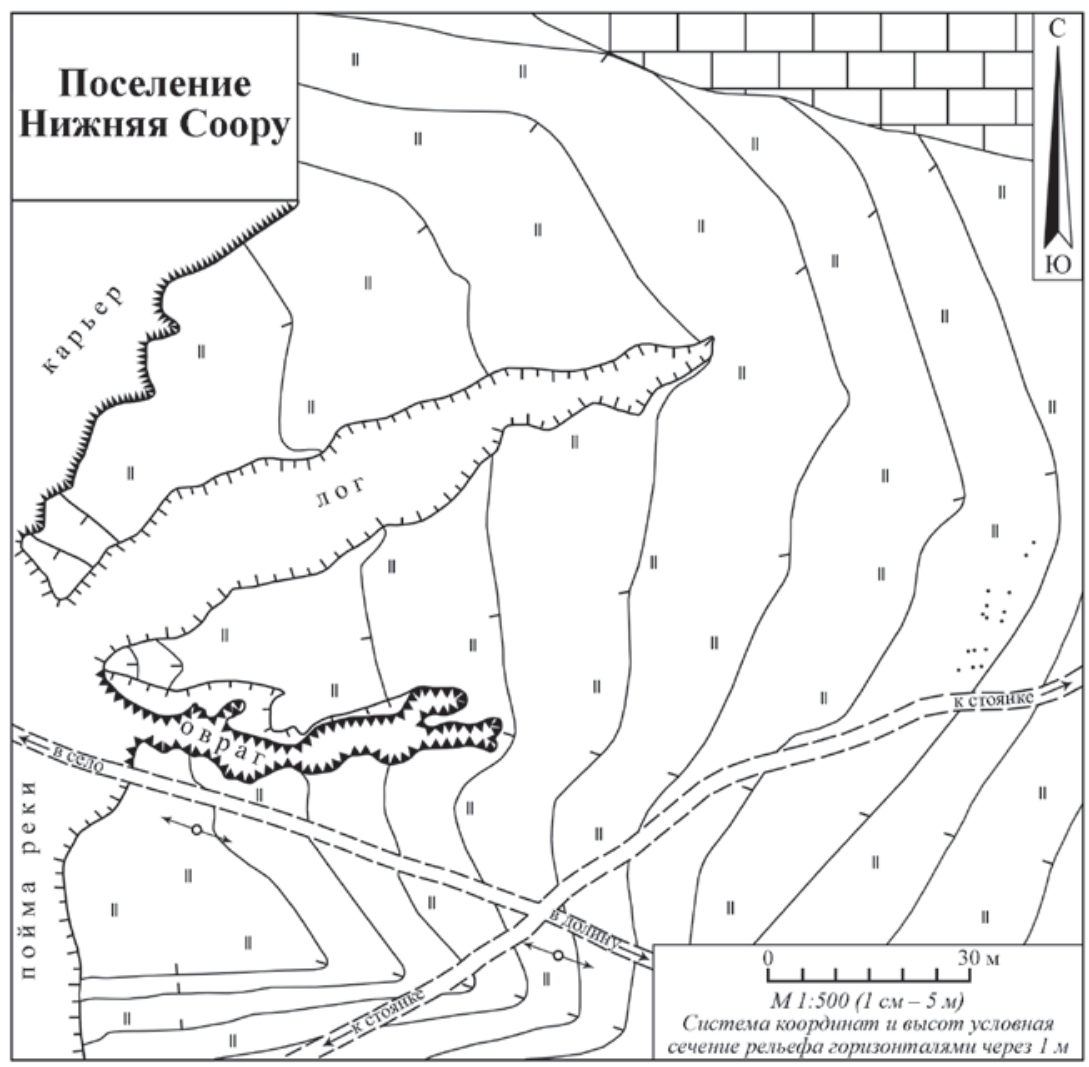

\section{Условные обозначения}

\begin{tabular}{|c|c|c|c|c|c|}
\hline uns & - граница карьера & ニニニニ & - полевая дорога & $\longleftrightarrow$ & - линия электропередач \\
\hline L & - граница лога & & - граница оврага & & - остепненный участок \\
\hline 15 & - горы & & - вертикальные камни & & иния горизонтали \\
\hline
\end{tabular}

Fig. 3. Nizhnyaya Sooru. Topographic plan

Рис. 3. Нижняя Соору. Тахеометрический план

\section{REFERENCES}

Abdulganeev M. T., Kiryushin Yu. F., Kadikov B. H. Materialy epohi bronzy iz Gornogo Altaya [Materials of the Bronze Age from Gorny Altai]. Arheologiya i etnografiya Altaya [Archaeology and Ethnography of Altai]. Barnaul: Izd-vo Alt. un-ta, 1982. Pp. 52-77. (In Russ.)

Afanas'evskij sbornik [Afanasyevsky Collection]. Otv. red. N. F. Stepanova, A. V. Polyakov. Barnaul : Azbuka, 2010.293 p. (In Russ.)

Afanas'evskij sbornik 2 [Afanasyevsky Collection 2] otv. red. N.F. Stepanova. Barnaul : Azbuka, 2012. 226 p. (In Russ.) 
Vadeckaya E. B., Polyakov A. V., Stepanova N. F. Svod pamyatnikov afanas'evskoj kul'tury [The Collection of Sites of Afanasyevo Culture] Barnaul : AZBUKA, 2014. 380 p. (In Russ.)

Grushin S. P., Papin D. V., Pozdnyakova O. A., Tyurina E. A., Fedoruk A. S., Havrin S. V. Altaj $\mathrm{v}$ sisteme metallurgicheskih provincij eneolita i bronzovogo veka [Altai in the System of Metallurgical Provinces of the Eneolithic and Bronze Age]. Barnaul : Izd-vo Alt. un-ta, 2006. 160 p.

Gryaznov M. P. Nekotorye voprosy istorii slozheniya i razvitiya rannih kochevyh obshchestv Kazahstana i Yuzhnoj Sibiri [Some Questions of the History of the Formation and Development of the Early Nomadic Societies of Kazakhstan and Southern Siberia]. Kratkie soobshcheniya Instituta etnografii [Brief Reports of the Institute of Ethnography]. M. : Izd-vo Akademii nauk SSSR, 1955. Vyp. XXIV. Pp. 19-29. (In Russ.)

Gryaznov M. P. Etapy razvitiya hozyajstva skotovodcheskih plemen Kazahstana i Yuzhnoj Sibiri v epohu bronzy [Stages of Development of the Economy of Pastoralist Tribes of Kazakhstan and southern Siberia in the Bronze Age]. Kratkie soobshcheniya Instituta etnografii [Brief Reports of the Institute of Ethnography]. M.: Izd-vo Akademii nauk SSSR, 1957. Vyp. XXVI. P. 21-28. (In Russ.)

Drevnie kul'tury Bertekskoj doliny (Gornyj Altaj, ploskogor'e Ukok) [Ancient Cultures of the Bertek Valley (Gorny Altai, Ukok Plateau)]. A. P. Derevyanko, V. I. Molodin, D. G. Savinov i dr. Novosibirsk: Nauka, 1994. 224 P. (In Russ.)

Dashkovskij P. K., Stepanova N. F. Inskoj Dol — pamyatnik epohi rannej bronzy v Zapadnom Altae [Inskoy Dol — a Site of the Early Bronze Age in Western Altai]. Arheologiya, etnografiya i antropologiya Evrazii [Archaeology, Ethnography and Anthropology of Eurasia]. 2018. T. 46, № 1. Pp. 41-50.(In Russ.) DOI: https://doi.org/10.17746/1563-0102.2018.46.1.041-050

Dashkovskij P. K. Kurgan epohi paleometalla iz mogil'nika Hankarinskij dol (Gornyj Altaj) [A Burial Mound of the Paleometal Era from the Khankarinsky Dol Burial Ground (Gorny Altai)]. Narody i religii Evrazii [Peoples and Religions of Eurasia]. 2019. №3 (20). Pp. 19-33. (In Russ.)

Elin V.N., Larin O. V. Obsledovanie avarijnyh pamyatnikov v Gornom Altae [Survey of Emergency Sites in Gorny Altai]. Sohranenie i izuchenie kul'turnogo naslediya Altajskogo kraya [Preservation and Study of the Cultural Heritage of the Altai Territory]. Barnaul : Izd-vo Alt. un-ta, 1998. Vyp. IX. Pp. 64-67. (In Russ.)

Ilyushin A. M. Drevnie i sovremennye kul'tovye mesta Altaya (dannye iz polevogo dnevnika avtora ob arheologicheskih issledovaniyah na Nizhnem Sooru v 1982 g.) [Ancient and Modern Places of Worship in Altai (Data from the Author's Field Diary on Archaeological Research on the Lower Soor in 1982)] Drevnie i sovremennye kul'tovye mesta Altaya [Ancient and Modern Places of Worship in Altai]. Barnaul : OOO “Pechatnaya kompaniya ARTIKA",2011. Pp. 11-13. (In Russ.)

Kiryushin Yu. F. Itogi i perspektivy izucheniya pamyatnikov eneolita i bronzy Altaya [Results and Prospects of Studying the Sites of the Eneolithic and Bronze of Altai]. Problemy drevnih kul'tur Sibiri [Problems of Ancient Cultures of Siberia]. Novosibirsk : [Bez izd-va], 1985. Pp. 46-53. (In Russ.)

Kiryushin Yu. F. Eneolit i rannyaya bronza yuga Zapadnoj Sibiri [Eneolithic and Early Bronze Age of the South of Western Siberia]. Barnaul : Izd-vo Alt. un-ta, 2002. 294 p. (In Russ.) 
Kiryushin Yu. F., Grushin S. P., Semibratov V.P., Tyurina E. A. Afanas'evskie pogrebal'nye kompleksy Srednej Katuni (rezul'taty issledovanij Katunskoj arheologicheskoj ekspedicii v zone stroitel'stva i zatopleniya Altajskoj GES v 2006-2007 gg.) [Afanasyevskaya Burial Complexes of the Middle Katun (Results of the Research of the Katunskaya Archaeological Expedition in the Zone of Construction and Flooding of the Altai Hydroelectric Power Station in 2006-2007)]. Barnaul: Izd-vo Alt. un-ta, 2010. 80 p. (In Russ.)

Kiryushin Yu. F., Tishkin A. A. Skifskaya epoha Gornogo Altaya. Ch. I: Kul'tura naseleniya v ranneskifskoe vremya [Scythian Era of Gorny Altai. Part I: Culture of the Population in the Early Scythian Time]. Barnaul : Izd-vo Alt. u-ta, 1997. 232 p. (In Russ.)

Kiselev S. V. Drevnyaya istoriya Yuzhnoj Sibiri. 2-e izd. [Ancient History of Southern Siberia. $2^{\text {nd }}$ ed]. M. : Izd-vo AN SSSR, 1951. 644 p. (In Russ.)

Kovalev A. A. Rasprostranenie afanas'evskoj kul'tury na territorii Sin'czyana: hronologicheskie ramki i tipologicheskie osobennosti [The Spread of Afanasyevo Culture in Xinjiang: Chronological Framework and Typological Features]. Fenomeny kul'tur rannego bronzovogo veka stepnoj i lesostepnoj polosy Evrazii: puti kul'turnogo vzaimodejstviya v V-III tys. do n.e. [Phenomena of the Cultures of the Early Bronze Age of the Steppe and Forest-steppe Zone of Eurasia: the Ways of Cultural Interaction in the 5-3 Millennium BC]. Orenburg : Orenburgskij gosudarstvennyj pedagogicheskij universitet, 2019. Pp. 188-209. (In Russ.)

Konstantinov N. A., Vavulin M. V, Zajceva O. V., Urbyshev A. U. Obsledovanie arheologicheskih pamyatnikov doliny reki Bol'shoj Ulagan (Vostochnyj Altaj) [Survey of Archaeological Sites in the Valley of the Bolshoi Ulagan River (Eastern Altai)]. Drevnosti Sibiri i Central'noj Azii: Elektronnoe izdanie [Antiquities of Siberia and Central Asia: Electronic Edition]. Gorno-Altajsk : GAGU, 2018. Pp. 17-33. (In Russ.)

Kosincev P. A. Fauna poseleniya Nizhnyaya Sooru [Fauna of the Settlement of Nizhnaya Sooru]. Larin O. V. Afanas'evskaya kul'tura Gornogo Altaya: mogil'nik Sal'dyar-1 [Larin O. V. Afanasyevskaya Culture of Gorny Altai: Burial Ground Saldiar-1]. Barnaul : Azbuka, 2005. Pp. 160-167. (In Russ.)

Kungurov A.L., Tishkin A. A. Eshche odin must'erskij pamyatnik v Gornom Altae [Another Mousterian Site in Gorny Altai] Drevnosti Altaya: Izvestiya laboratorii arheologii [Altai Antiquities: Proceedings of the Laboratory of Archaeology]. Gorno-Altajsk : Gorno-Altajskij gos. un-t, 2000. №5. Pp. 4-7. (In Russ.)

Larin O. V. K istorii izucheniya afanas'evskoj kul'tury Gornogo Altaya [On the History of the Study of the Afanasyev Culture of Gorny Altai]. Arheologiya Gornogo Altaya [Archaeology of Altai Mountains]. Gorno-Altajsk : GANIIIYaL, 1988. Pp. 82-91. (In Russ.)

Larin O. V. Afanas'evskaya kul'tura Gornogo Altaya: mogil'nik Sal'dyar-I [Afanasyevskaya Culture of Gorny Altai: Saldiar-I Burial Ground]. Barnaul : Izd-vo Alt. un-ta, 2005. 208 p. (In Russ.)

Larin O. V., Kungurova N. Yu., Stepanova N. F. Poselenie afanas'evskoj kul'tury Nizhnyaya Sooru [Settlement of Afanasyevsk Culture Nizhnaya Sooru]. Sohranenie i izuchenie kul'turnogo naslediya Altajskogo kraya [Preservation and Study of the Cultural Heritage of the Altai Territory]. Barnaul : Izd-vo Alt. un-ta, 1998. Vyp. IX. Pp. 67-73. (In Russ.)

Mamadakov Yu. T., Stepanova N. F. Afanas'evskie poseleniya Lamah-2 i Bichiktu-Bom [Afanasyevsk Settlements Laman-2 and Bichiktu-Bom]. Sohranenie i izuchenie kul'turnogo 
naslediya Altajskogo kraya [Preservation and Study of the Cultural Heritage of the Altai Territory]. Barnaul : Izd-vo Alt. un-ta, 1998. Vyp. IX. Pp. 73-77. (In Russ.)

Masson V. M. Kul'tura v ponyatijnom apparate arheologii [Culture in the Conceptual Apparatus of Archaeology] Yuzhnaya Sibir' v skifo-sarmatskuyu epohu [Southern Siberia in the Scythian-Sarmatian Era]. Kemerovo : KemGU, 1976. Pp. 3-7. (In Russ.)

Merc I. V. Afanas'evskie pamyatniki Vostochnogo Kazahstana [Afanasyevsky Sites of East Kazakhstan]. Arheologicheskie pamyatniki Yuzhnoj Sibiri i Central'noj Azii: ot poyavleniya pervyh skotovodov do epohi slozheniya gosudarstvennyh obrazovanij [Archaeological Sites of Southern Siberia and Central Asia: from the Appearance of the First Pastoralists to the Era of the Formation of state Formations]. SPb. : IIMK RAN, 2021. Pp. 39-42. (In Russ.)

Muhareva A. N., Miklashevich E. A., Seregin N. N. Izobrazheniya na stele iz pogrebal'nopominal'nogo kompleksa Nizhnyaya Sooru (Gornyj Altaj) [Images on a Stele from the Burial and Memorial Complex of Nizhnaya Sooru (Gorny Altai)]. Problemy istorii, filologii, kul'tury [Problems of History, Philology, Culture]. 2021. №2 (72). Pp. 188-210. (In Russ.)

Polyakov A. V., Svyatko S. V. Radiouglerodnoe datirovanie arheologicheskih pamyatnikov neolita - nachala zheleznogo veka Srednego Eniseya: obzor rezul'tatov i novye dannye [Radiocarbon Dating of Archaeological Sites of the Neolithic - Early Iron Age of the Middle Yenisei: a Review of the Results and New Data]. Teoriya i praktika arheologicheskih issledovanij [Theory and Practice of Archaeological Research]. Barnaul : Izd-vo Alt. un-ta, 2009. Vyp. 5. Pp. 20-56. (In Russ.)

Pogozheva A.P., Rykun M.P., Stepanova N. F., Tur S. S. Epoha eneolita i bronzy Gornogo Altaya. Ch. 1 [The Eneolithic and Bronze Age of Gorny Altai. Part 1]. Barnaul : [bez izd-va], 2006. 233 p. (In Russ.)

Pogrebal'nye i poselencheskie kompleksy epohi bronzy Gornogo Altaya [Burial and Settlement Complexes of the Bronze Age in Gorny Altai]. Otv. red. N. F. Stepanova. Barnaul : Izd-vo Alt. un-ta, 2006. 154 p. (In Russ.)

Rudenko S. I. Pogrebenie cheloveka kamennogo veka v Vostochnom Altae [Burial of a Stone Age Man in Eastern Altai]. Priroda [Nature]. 1926. № 5-6. Pp. 108-109. (In Russ.)

Seregin N. N., Vasyutin S. A. Ritual'nye ob»ekty perioda eneolita v urochishche Nizhnyaya Sooru (Central'nyj Altaj): po materialam raskopok A.S. Vasyutina [Ritual Objects of the Eneolithic Period in the Lower Sooru Tract (Central Altai): Based on Materials from the Excavations of A.S. Vasyutin]. Teoriya i praktika arheologicheskih issledovanij [Theory and Practice of Archaeological Research]. 2020. T. 31, № 3. Pp. 90-98. (In Russ.) DOI: https://doi. org/10.14258/tpai(2020)3(31).-08

Seregin N. N., Vasyutin S. A. Rannetyurkskie arheologicheskie kompleksy Central'nogo i Vostochnogo Altaya (po materialam issledovanij A.S. Vasyutina) [Early Turkic Archaeological Complexes of Central and Eastern Altai (Based on Research by A.S. Vasyutin)]. Barnaul : Izd-vo Alt. un-ta, 2021. 296 p. (In Russ.)

Sosnovskij G. P. Ojrotskaya Avtonomnaya oblast', 1936 g. [Oirot Autonomous Region, 1936]. Arheologicheskie issledovaniya v RSFSR 1934-36 gg. Kratkie otchety i svedeniya [Archaeological Research in the RSFSR 1934-36. Brief Reports and Details]. M.; L. : Izd-vo Akad. nauk SSSR, 1941. Pp. 304-306. (In Russ.) 
Stepanova N.F. Afanas'evskaya kul'tura [Afanasyevskaya Culture] Istoriya Altaya: v 3 t. T. 1: Drevnejshaya epoha, drevnost' i srednevekov'e [History of Altai: in 3 Vol. Vol. 1: The Most Ancient Era, Antiquity and the Middle Ages]. Barnaul : Izd-vo Alt. un-ta ; Belgorod : Konstanta, 2019. Pp. 114-124. (In Russ.)

Surazakov A. S., Tishkin A. A. Arheologicheskij kompleks Kyzyk-Telan' - I v Gornom Altae i rezul'taty ego izucheniya [Archaeological Complex Kyzyk-Telan-I in Gorny Altai and the Results of its Study]. Barnaul : Azbuka, 2007. 232 p. (In Russ.)

Tishkin A.A. Arheologicheskie mikrorajony na Altae kak osnova dlya sozdaniya osobo ohranyaemyh territorij (na primere vyyavlennyh i izuchennyh pamyatnikov v doline r. Bol'shoj Yaloman) [Archaeological Microdistricts in Altai as a Basis for the Creation of Specially Protected Areas (on the Example of Identified and Studied Sites in the Valley of the Bolshoy Yaloman River)]. Znachenie prirodnogo i kul'turnogo naslediya v sovremennom obshchestve [The Importance of Natural and Cultural Heritage in Modern Society]. Gorno-Altajsk : OOO “Gorno-Altajskaya tipografiya", 2018. Pp. 29-33. (In Russ.)

Tishkin A. A., Seregin N. N. Eneoliticheskie ob'ekty Urkoshskogo i Kur-Kechuskogo arheologicheskih mikrorajonov (Central'nyj Altaj) [Eneolithic Objects of the Urkos and KurKechu Archaeological Microdistricts (Central Altai)]. Afanas'evskij sbornik 2 [Afanasyevsky Collection 2]. Barnaul : Azbuka, 2012. Pp. 196-203. (In Russ.)

Fribus A. V. Proiskhozhdenie afanas'evskoj kul'tury : avtoreferat dis. ... kand. ist. nauk [The Origin of Afanasyev Culture: Abstract of dis. ... Cand. Hist. Sciences]. Kemerovo, 1998. 26 p. (In Russ.)

Fribus A.V. K diskussii o proiskhozhdenii afanas'evskoj kul'tury [To a Discussion about the Origin of the Afanasyev Culture]. Sovremennye problemy arheologii Rossii [Modern Problems of Archaeology in Russia]. Novosibirsk : Izd-vo In-ta arheologii i etnografii, 2006. T. I. Pp. 478-480. (In Russ.)

Cyb S. V. Afanas'evskaya kul'tura Altaya : avtoreferat dis. ... kand. ist. nauk [Afanasyev Altai Culture: Abstract of dis. ... Cand. Hist. Sciences]. Kemerovo, 1984. 19 p. (In Russ.)

Shul'ga P. I. O hozyajstve afanas'evcev Gornogo Altaya [About the Economy of Afanasyevites in Gorny Altai]. Afanas'evskij sbornik 2 [Afanasyevsky Collection 2]. Barnaul : Azbuka, 2012. Pp. 204-209. (In Russ.)

Allentoft M.E., Sikora M., Sjogren K.-G., Rasmussen S., Rasmussen M., Stenderup J., Damgaard P. B., Schroeder H., Ahlstrom T., Vinner L., Malaspinas A.-S., Margaryan A., Higham T., Chivall D., Lynnerup N., Harvig L., Baron J., Casa P. D., Dąbrowski P., Duffy P. R., Ebel A. V., Epimakhov A., Frei K., Furmanek M., Gralak T., Gromov A., Gronkiewicz S., Grupe G., Hajdu T., Jarysz R., Khartanovich V., Khokhlov A., Kiss V., Kolař J., Kriiska A., Lasak I., Longhi C., McGlynn G., Merkevicius A., Merkyte I., Metspalu M., Mkrtchyan R., Moiseyev V., Paja L., Palfi G., Pokutta D., Pospieszny Ł., Price T.D., Saag L., Sablin M., Shishlina N., Smrčka V., Soenov V. I., Szeverenyi V., Toth G., Trifanova S. V., Varul L., Vicze M., Yepiskoposyan L., Zhitenev V., Orlando L., Sicheritz-Ponten T., Brunak S., Nielsen R., Kristiansen K., Willerslev E. Population genomics of Bronze Age Eurasia Nature. 2015. Vol. 522. Pp. 167-172. DOI: https://doi.org/10.1038/nature14507

Hermes T. R., Tishkin A.A., Kosintsev P. A., Stepanova N. F., Krause-Kyora B., Makarewicz C. A. Mitochondrial DNA of Domesticated Sheep Confirms Pastoralist 
Component of Afanasievo Subsistence Economy in the Altai Mountains (3300-2900 cal BC). Archaeological Research in Asia. 2020. 24, 100232. DOI: https://doi.org/10.1016/j. ara.2020.100232

Honeychurch W., Rogers L., Amartuvshin Ch., Diimaajav E., Erdene-Ochir N-O., Hall M.E., and M. Hrivnyak. The Earliest Herders of East Asia: Examining Afanasievo Entry to Central Mongolia. Archaeological Research in Asia. 2021. DOI: https://doi.org/10.1016/j. ara.2021.100264.

\section{БИБЛИОГРАФИЧЕСКИЙ СПИСОК}

Абдулганеев М.Т., Кирюшин Ю.Ф., Кадиков Б. Х. Материалы эпохи бронзы из Горного Алтая // Археология и этнография Алтая. Барнаул : Изд-во Алт. ун-та, 1982. С. 52-77.

Афанасьевский сборник / отв. ред. Н.Ф. Степанова, А. В. Поляков. Барнаул : Азбука, 2010. 293 с.

Афанасьевский сборник 2 / отв. ред. Н.Ф. Степанова. Барнаул : Азбука, 2012. 226 с.

Вадецкая Э. Б., Поляков А. В., Степанова Н. Ф. Свод памятников афанасьевской культуры. Барнаул : АЗБУКА, 2014. 380 с.

Грушин С. П., Папин Д. В., Позднякова О.А., Тюрина Е.А., Федорук А. С., Хаврин С.В. Алтай в системе металлургических провинций энеолита и бронзового века. Барнаул : Изд-во Алт. ун-та, 2009. 160 с.

Грязнов М.П. Некоторые вопросы истории сложения и развития ранних кочевых обществ Казахстана и Южной Сибири // Краткие сообщения Института этнографии. М. : Изд-во Академии наук СССР, 1955. Вып. XXIV. С. 19-29.

Грязнов М. П. Этапы развития хозяйства скотоводческих племен Казахстана и Южной Сибири в эпоху бронзы // Краткие сообщения Института этнографии. М. : Изд-во Академии наук СССР, 1957. Вып. XXVI. С. 21-28.

Древние культуры Бертекской долины (Горный Алтай, плоскогорье Укок) / А. П. Деревянко, В. И. Молодин, Д. Г. Савинов и др. Новосибирск : Наука, 1994. 224 с.

Дашковский П.К., Степанова Н.Ф. Инской Дол - памятник эпохи ранней бронзы в Западном Алтае // Археология, этнография и антропология Евразии. 2018. Т. 46, № 1. C. 41-50. DOI: https://doi.org/10.17746/1563-0102.2018.46.1.041-050

Дашковский П.К. Курган эпохи палеометалла из могильника Ханкаринский дол (Горный Алтай) // Народы и религии Евразии. 2019. № 3 (20). С. 19-33.

Елин В.Н., Ларин О. В. Обследование аварийных памятников в Горном Алтае // Сохранение и изучение культурного наследия Алтайского края. Барнаул : Изд-во Алт. ун-та, 1998. Вып. ІХ. С. 64-67.

Илюшин А. М. Древние и современные культовые места Алтая (данные из полевого дневника автора об археологических исследованиях на Нижнем Соору в 1982 г.) // Древние и современные культовые места Алтая. Барнаул : ООО «Печатная компания АРТИКА», 2011. С. 11-13.

Кирюшин Ю. Ф. Итоги и перспективы изучения памятников энеолита и бронзы Алтая // Проблемы древних культур Сибири. Новосибирск : [Без изд-ва], 1985. С. 46-53.

Кирюшин Ю.Ф. Энеолит и ранняя бронза юга Западной Сибири. Барнаул : Изд-во Алт. ун-та, 2002. 294 с. 
Кирюшин Ю.Ф., Грушин С. П., Семибратов В. П., Тюрина Е. А. Афанасьевские погребальные комплексы Средней Катуни (результаты исследований Катунской археологической экспедиции в зоне строительства и затопления Алтайской ГЭС в 2006-2007 гг.). Барнаул: Изд-во Алт. ун-та, 2010. 80 с.

Кирюшин Ю.Ф., Тишкин А.А. Скифская эпоха Горного Алтая. Ч. І: Культура населения в раннескифское время. Барнаул : Изд-во Алт. у-та, 1997. 232 с.

Киселев С. В. Древняя история Южной Сибири. 2-е изд. М. : Изд-во АН СССР, 1951. $644 \mathrm{c}$.

Ковалев А. А. Распространение афанасьевской культуры на территории Синьцзяна: хронологические рамки и типологические особенности // Феномены культур раннего бронзового века степной и лесостепной полосы Евразии: пути культурного взаимодействия в V-III тыс. до н.э. Оренбург : Оренбургский государственный педагогический университет, 2019. С. 188-209.

Константинов Н.А., Вавулин М. В, Зайцева О.В., Урбышев А. У. Обследование археологических памятников долины реки Большой Улаган (Восточный Алтай) // Древности Сибири и Центральной Азии: Электронное издание. Горно-Алтайск : ГАГУ, 2018. C. 17-33.

Косинцев П. А. Фауна поселения Нижняя Соору // Ларин О. В. Афанасьевская культура Горного Алтая: могильник Сальдяр-1. Барнаул : Азбука, 2005. С. 160-167.

Кунгуров А. Л., Тишкин А.А. Еще один мустьерский памятник в Горном Алтае // Древности Алтая: Известия лаборатории археологии. Горно-Алтайск : Горно-Алтайский гос. ун-т, 2000. № 5. С. 4-7.

Ларин О.В. К истории изучения афанасьевской культуры Горного Алтая // Археология Горного Алтая. Горно-Алтайск : ГАНИИИЯЛ, 1988. С. 82-91.

Ларин О.В. Афанасьевская культура Горного Алтая: могильник Сальдяр-I. Барнаул : Изд-во Алт. ун-та, 2005. 208 с.

Ларин О. В., Кунгурова Н. Ю., Степанова Н. Ф. Поселение афанасьевской культуры Нижняя Соору // Сохранение и изучение культурного наследия Алтайского края. Барнаул : Изд-во Алт. ун-та, 1998. Вып. IX. С. 67-73.

Мамадаков Ю.Т., Степанова Н. Ф. Афанасьевские поселения Ламах-2 и БичиктуБом // Сохранение и изучение культурного наследия Алтайского края. Барнаул : Изд-во Алт. ун-та, 1998. Вып. ІХ. С. 73-77.

Массон В.М. Культура в понятийном аппарате археологии // Южная Сибирь в скифо-сарматскую эпоху. Кемерово : КемГУ, 1976. С. 3-7.

Мерц И.В. Афанасьевские памятники Восточного Казахстана // Археологические памятники Южной Сибири и Центральной Азии: от появления первых скотоводов до эпохи сложения государственных образований. СПб. : ИИМК РАН, 2021. С. 39-42.

Мухарева А.Н., Миклашевич Е.А., Серегин Н.Н. Изображения на стеле из погребально-поминального комплекса Нижняя Соору (Горный Алтай) // Проблемы истории, филологии, культуры. 2021. № 2 (72). С. 188-210.

Поляков А. В., Святко С. В. Радиоуглеродное датирование археологических памятников неолита - начала железного века Среднего Енисея: обзор результатов и новые дан- 
ные // Теория и практика археологических исследований. Барнаул : Изд-во Алт. ун-та, 2009. Вып. 5. С. 20-56.

Погожева А.П., Рыкун М.П., Степанова Н.Ф., Тур С.С. Эпоха энеолита и бронзы Горного Алтая. Ч. 1. Барнаул : [без изд-ва], 2006. 233 с.

Погребальные и поселенческие комплексы эпохи бронзы Горного Алтая / отв. ред. Н. Ф. Степанова. Барнаул : Изд-во Алт. ун-та, 2006. 154 с.

Руденко С.И. Погребение человека каменного века в Восточном Алтае // Природа. 1926. №5-6. С. 108-109.

Серегин Н.Н., Васютин С.А. Ритуальные объекты периода энеолита в урочище Нижняя Соору (Центральный Алтай): по материалам раскопок А. С. Васютина // Теория и практика археологических исследований. 2020. Т. 31, № 3. С. 90-98. DOI:https:// doi.org/10.14258/tpai(2020)3(31).-08

Серегин Н.Н., Васютин С. А. Раннетюркские археологические комплексы Центрального и Восточного Алтая (по материалам исследований А.С. Васютина). Барнаул : Изд-во Алт. ун-та, 2021. 296 с.

Сосновский Г. П. Ойротская Автономная область, 1936 г. // Археологические исследования в РСФСР 1934-36 гг. Краткие отчеты и сведения. М.; Л. : Изд-во Акад. наук CCCP, 1941. C. 304-306.

Степанова Н.Ф. Афанасьевская культура // История Алтая : в 3 т. Т. 1 : Древнейшая эпоха, древность и средневековье. Барнаул : Изд-во Алт. ун-та ; Белгород : Константа, 2019. С. 114-124.

Суразаков А. С., Тишкин А.А. Археологический комплекс Кызык-Телань-І в Горном Алтае и результаты его изучения. Барнаул : Азбука, 2007. 232 с.

Тишкин А. А. Археологические микрорайоны на Алтае как основа для создания особо охраняемых территорий (на примере выявленных и изученных памятников в долине р. Большой Яломан) // Значение природного и культурного наследия в современном обществе. Горно-Алтайск : ООО «Горно-Алтайская типография», 2018. С. 29-33.

Тишкин А.А., Серегин Н.Н. Энеолитические объекты Уркошского и Кур-Кечуского археологических микрорайонов (Центральный Алтай) // Афанасьевский сборник 2. Барнаул : Азбука, 2012. С. 196-203.

Фрибус А. В. Происхождение афанасьевской культуры : автореф. дис. ... канд. ист. наук. Кемерово, 1998. 26 с.

Фрибус А. В. К дискуссии о происхождении афанасьевской культуры // Современные проблемы археологии России. Новосибирск : Изд-во Ин-та археологии и этнографии, 2006. Т. I. С. 478-480.

Цыб С. В. Афанасьевская культура Алтая : автореферат дис. ... канд. ист. наук. Кемерово, 1984. 19 с.

Шульга П.И. О хозяйстве афанасьевцев Горного Алтая // Афанасьевский сборник 2. Барнаул : Азбука, 2012. С. 204-209.

Allentoft M.E., Sikora M., Sjogren K.-G., Rasmussen S., Rasmussen M., Stenderup J., Damgaard P. B., Schroeder H., Ahlstrom T., Vinner L., Malaspinas A.-S., Margaryan A., Higham T., Chivall D., Lynnerup N., Harvig L., Baron J., Casa P. D., Dąbrowski P., Duffy P. R., Ebel A. V., Epimakhov A., Frei K., Furmanek M., Gralak T., Gromov A., Gronkiewicz S., 
Grupe G., Hajdu T., Jarysz R., Khartanovich V., Khokhlov A., Kiss V., Kolař J., Kriiska A., Lasak I., Longhi C., McGlynn G., Merkevicius A., Merkyte I., Metspalu M., Mkrtchyan R., Moiseyev V., Paja L., Palfi G., Pokutta D., Pospieszny Ł., Price T. D., Saag L., Sablin M., Shishlina N., Smrčka V., Soenov V. I., Szeverenyi V., Toth G., Trifanova S. V., Varul L., Vicze M., Yepiskoposyan L., Zhitenev V., Orlando L., Sicheritz-Ponten T., Brunak S., Nielsen R., Kristiansen K., Willerslev E. Population genomics of Bronze Age Eurasia // Nature. 2015. Vol. 522. Pp. 167-172. DOI: https://doi.org/10.1038/nature14507

Hermes T. R., Tishkin A.A., Kosintsev P. A., Stepanova N. F., Krause-Kyora B., Makarewicz C. A. Mitochondrial DNA of domesticated sheep confirms pastoralist component of Afanasievo subsistence economy in the Altai Mountains (3300-2900 cal BC) // Archaeological Research in Asia. 2020. 24, 100232. DOI: https://doi.org/10.1016/j.ara.2020.100232

Honeychurch W., Rogers L., Amartuvshin Ch., Diimaajav E., Erdene-Ochir N-O., Hall M.E., and M. Hrivnyak. The earliest herders of East Asia: Examining Afanasievo entry to central Mongolia // Archaeological Research in Asia. 2021. DOI: https://doi.org/10.1016/j. ara.2021.100264.

\section{INFORMATION ABOUT THE AUTHORS / ИНФОРМАЦИЯ ОБ АВТОРАХ}

Alexey Alexeevich Tishkin, Doctor of Historical Sciences, Professor, Head of Department of Archaeology, Ethnography and Museology, Altai State University, Barnaul, Russian Federation.

Тишкин Алексей Алексеевич, доктор исторических наук, профессор, заведующий кафедрой археологии, этнографии и музеологии Алтайского государственного университета, г. Барнаул, Российская Федерация.

Taylor Hermes, Ph.D., Postdoctoral researcher, Max Planck Institute for Evolutionary Anthropology, Leipzig, Germany.

Гермес Тейлор, Ph.D., постдокторант, Институт эволюционной антропологии Макса Планка, г. Лейпциг, Германия.

Sergei Petrovich Grushin, Doctor of Historical Sciences, Professor of Department of Archaeology, Ethnography and Museology, Altai State University, Barnaul, Russian Federation.

Грушин Сергей Петрович, доктор исторических наук, профессор кафедры археологии, этнографии и музеологии Алтайского государственного университета, г. Барнаул, Российская Федерация.

Материал поступил в редколлегию 06.06.2021. Статья принята в номер 16.08.2021. 